\title{
The traditional periodization in individual sports: providing effective responses to both new and old problems
}

\section{Periodización tradicional: dando soluciones a los viejos y nuevos problemas}

\author{
José María González Ravé \\ Director of Sport Performance Research Group (GIRD). Facultad de Ciencias del Deporte. Universidad de Castilla la Mancha.
}

doi: 10.18176/archmeddeporte.00028

Performance in individual events require an unique combination of different multi-factorial (psychological, physical, technical) capacities. To target these characteristics and elicit specific adaptations, training must be focused on the desired elements of performance ${ }^{1}$. Moreover, performance is multidimensional, making the quantification of the load a complex issue. The desirable prediction of performance of any athlete is extremely difficult in the upcoming months which preceding a major international competition. The periodization of training based on individual responses to optimize the training process can be conceptualized as a logical sequential of manipulating fitness and recovery phases, following principles of specificity, overload and recovery to achieve high levels of sports performance at the most important competitions.

The inception of this concept in the XX century is dated around 1952-1956. The USSR team achieved the second position in the Olympics because the athletes had not achieved their best performances at the time of the Olympics. Then, a young researcher was asked to find how to peak performance at the right time: Lev Matveev (1924-2006) [transcription in English from the original in Russian] wrote his doctoral dissertation on the problem. The theoretical basis of training was not novel, Matveev based his ideas about periodization on the Theory of Lauri Pihkala (coach of Paavo Nurmi), Hans Selye (General Adaptation Syndrome [GAS]), Pavlov (stimulus-response, conditioned reflexes), and Yakolev (supercompensation). His dissertation substantially modified the philosophy of training, its organization and science, and became on the basis for the international success of the Eastern Block. Matveev's theory was applied on soviet athletes for the first time at the 1960 Olympic Games and USSR was the winner on the medal table. A common criticism of this success has been due to the likely (and in many cases confirmed) use of androgens, however, it is worth noting that androgen use was not confined to the GDR and the USSR, in fact, far from it, as androgen use was common in many countries during this period. Thus, the idea that their success was solely due to drug use is at best an oversimplification.

In the USA, J. Garhammer published one of the first papers dealing with periodization specifically for strength training in athletes, particularly for strength power events. The classical model was also developed and evolved by recognizable swimming coaches as James Counsilman (USA) and Forbes Carlile (AUS).

However, his colleagues at the time often questioned the basis of Matveev's work. If only elite athletes are recruited for analyzing the validity of the traditional model, the usage of parametric statistics is more than doubtful. Those athletes are at the very end of a normal distribution curve, so they do not follow a normal distribution for a correct experimental design². Although Matveyev originally dealt with elite and high-level athletes, an advantage of Matveyev's conceptual paradigm was that it could be applied to athletes of any level in contrast with the criticism of other soviet sport scientific (e.g. Vladimir Zatziorsky).

The known "traditional periodization" has not been indifferent to controversial positioning of different theories which are reflected in the scientific literature. Two important issues have been discussed in the literature. Firstly, traditional periodization has been criticised by authors from the Eastern countries. Several sports scientists and coaches, including Bondarchuk, Verkoshansky and Issurin noted potential problems with the traditional periodization paradigm. A contemporary of Matveyev, Yury Verkoshanky was a sport scientist, working primarily with track and field, who developed the Conjugated Successive System of Training as an alternative to traditional periodization models. Issurin, contemporary with both Matveyev and Verkoshanky also noted potential problems with the traditional concept and developed the Block Periodization model. Verkhoshansky also criticized the technique used to manage periodization [training units] as rudimentary, "... knowing the typical microcycles, which are formed like children's construction 
blocks, the following larger part (mesocycles) that in turn configure the large microcycles..." ${ }^{\prime 3}$. Issurin ${ }^{4}$ mentioned the need to change the old theory of training and accept a new implementation of the modern demands for competitive athletes. The same author highlighted a few weak points in the traditional periodization as frequent performance peaks within the same competition year, and a deep and specialised focus on the effects of training in a relatively short time. It was due to a change in the international rules for amateur athletes in 1981, allowing athletes to accept money for competition, precipitated considerable discussion and debate as to whether an athlete should be in good shape over a relatively long time or an excellent shape for a single major event. Because of this change many athletes, particularly in track and field, started to modify their training according to "market" rules². Rather than trying to peak when it counted, athletes had to perform over relatively long-terms, often to make a decent living ${ }^{2}$. This alteration in rules and changes in the competition calendar of many sports began to alter training considerations and methods.

Besides, the criticism of the periodization in the last years ${ }^{5}$ supports the idea about how periodization dictates should be understood as hypothetical and tradition-driven assumptions rather than evidence-led constructs. Kiely ${ }^{5}$ questioned the classical periodization paradigm used in different articles selected, asserting that Selye's Theory of the GAS as a generic predictable biological response should be formulated towards neurobiological aspects of human performance. Cunanan et al. ${ }^{6}$ argued that GAS has proven to be an instructive framework for understanding the training needed to induce functional adaptations. From our point of view, a periodized program may be advantageous given the need to plan training around practice and competitions throughout the season.

In addition, Kiely ${ }^{5}$ also criticized the concept of periodization because he considered that it was not "flexible" enough to meet the athlete's needs. Conversely, Cunnagan et al. ${ }^{6}$ affirm that this type of criticism usually stems from the often erroneously stated and very typical confusion of periodization with programming. The terms periodization and programming has been wrongly interchangeable by the researchers. The periodization is conceptualized as the macro-management of the training process concerning the annual plan. Whereas periodization (long-term global organisation of training) and programming (shortterm prescription of training sessions and sets) are different.

The sports scientists have evolved numerous and different periodization approaches including traditional, blocks, and other variations such as flexible (day-by-day), reverse, each offer a differing rationale and template for the sub-division of the program into sequential elements.

However, a recent systematic review of González-Ravé et al.'7 aimed to identify the main characteristics of endurance training for highlytrained swimmers. The results showed as the traditional version of periodization ${ }^{8-10}$ was the model conducted in the majority of studies. The traditional model has been the staple of many swimming coach education programs for several decades and enjoys substantial popularity in high performance swimming in many countries, although the fact that other periodization models have not been examined in the literature according to the inclusion criteria of this study does not necessarily imply that they would not be effective in elite swimmers.

Designing training programs is challenging to induce optimal training adaptations and maximize performance for athletes. Despite traditional training periodization provides coaches and athletes basic guidelines for structuring and planning an effective training for twothree peaks of performance. This periodization has resulted successful at present in individual sports as shown Solli et al. ${ }^{11}$ or Arroyo et al. ${ }^{12}$. A major limitation of this approach is its inability to elicit multiple peaks for repeated competitions over the competitive season as required the contemporary elite sport.

\section{References}

1. Reilly T, Morris T, Whyte G. The specificity of training prescription and physiological assessment: A review'. Journal of Sports Sciences. 2009;27:6:575-89.

2. Arnd Krüger. Bons baisers de Russie? Soixante années d'expansion du concept de planification sportive de LP Matwejew. Staps. 2016;4(114):51-9.

3. Platonov VN. El concepto de la periodización del entrenamiento y el desarrollo de una teoría del entrenamiento. INFOCOES. 2000;5(1):87-93. Traducción de Leitungsport $1 / 1999$.

4. Issurin V. New horizons for the methodology and physiology of training periodization. Sports Med. 2010;40(3):189-206.

5. Kiely, J. Periodization Theory: Confronting an Inconvenient Truth. Sports Med. 2018;48: 753-64. https://doi.org/10.1007/s40279-017-0823-y

6. Cunanan AJ, DeWeese BH, Wagle JP, Carroll KM, Sausaman R, Hornsby WG $3^{\text {rd }}$, et al. The general adaptation syndrome: a foundation for the concept of periodization. Sports Med. 2018;48(4):787-97. doi:10.1007/s40279-017-0855-3.

7. González Ravé JM, Hermosilla F, González-Mohino F, Pyne DB. Training intensity distribution, training volume and periodization models in elite swimmers: a systematic review. International Journal of Sports Physiology and Performance. In press. 2021.

8. Stewart AM, Hopkins WG. Seasonal training and performance of competitive swimmers. J Sports Sci. 2000;18(11):873-884. doi:10.1080/026404100750017805.

9. Hellard $\mathrm{P}$, Avalos-Fernandes M, Lefort $\mathrm{G}$, et al. Elite swimmers' training patterns in the 25 weeks prior to their season's best performances: insights into periodization from a 20-years cohort. Front Physiol. 2019; 10:363. doi:10.3389/fphys.2019.00363

10. Hellard P, Scordia C, Avalos M, Mujika I, Pyne DB. Modelling of optimal training load patterns during the 11 weeks preceding major competition in elite swimmers. Appl Physiol Nutr Metab. 2017;42(10):1106-17. doi:10.1139/apnm-2017-0180.

11. Solli GS, Tønnessen E, Sandbakk $\varnothing$. The Training Characteristics of the World's Most Successful Female Cross-Country Skier. Front. Physiol. 2017;8:1069. doi: 10.3389/ fphys.2017.01069.

12. Arroyo-Toledo JJ, Clemente VJ, Gonzalez-Rave JM, Ramos Campo DJ, Sortwell A. Comparison between traditional and reverse periodization: swimming performance and specific strength values. Int J Swim Kinet. 2013;2:87-96. 


\section{Analizador Instantáneo de Lactato

- Sólo 0,3 $\mu$ l de sangre

- Determinación en 15 segundos

- Más pequeño que su antecesor

- Calibración automática

- Memoria para 330 determinaciones

- Conexión a PC

- Rango de lectura: 0,5-25,0 mmol/litro

- Conservación de tiras reactivas a temperatura ambiente y

- Caducidad superior a un año

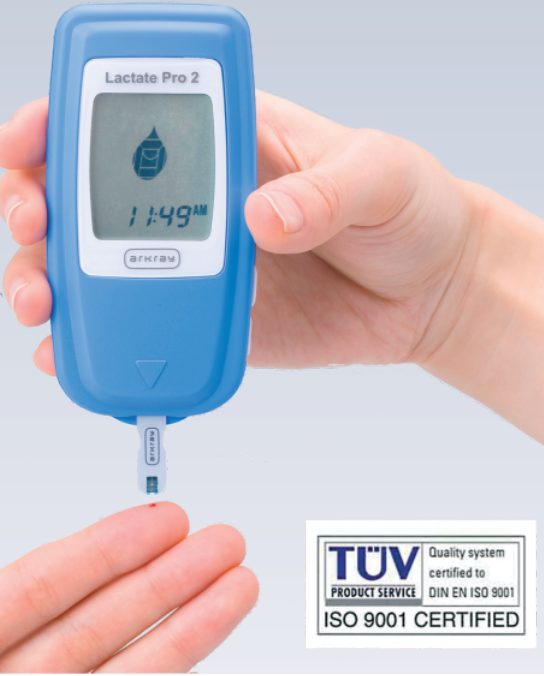

Importador para España:

froncisco j.bermel

ELECTROMED) ICINA

wuw.bermellelectromedicino.com EQUIPOS PARA EL DEPORTEY LA MEDICINA DEL DEPORTE

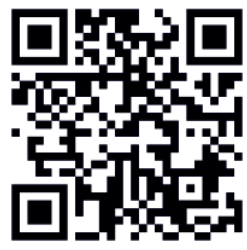

@BermellElectromedicina c/ Lto. Gabriel Miro, 54, ptas. 7 y 9 46008 Valencia Tel: 963857395 Móvil: 608848455 Fax: 963840104 info@bermellelectromedicina.com www.bermellelectromedicina.com

\section{Bermell Electromedicina}

\section{Y}

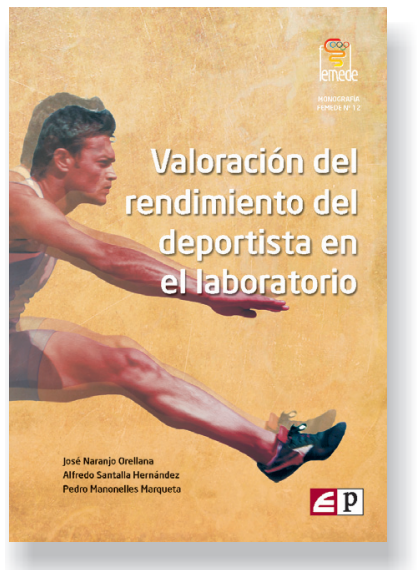

Monografías Femede $\mathrm{n}^{\circ} 12$ Depósito Legal: B. 27334-2013 ISBN: 978-84-941761-1-1 Barcelona, 2013 560 páginas.

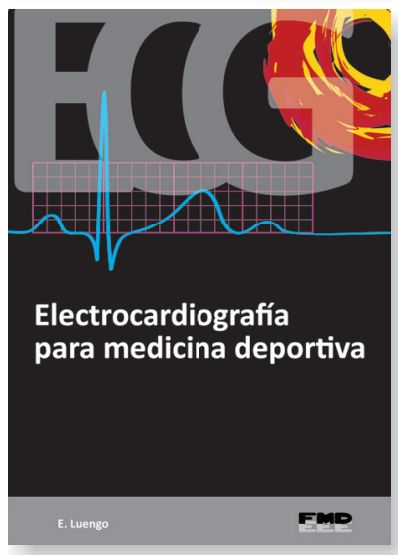

ISBN: 978-84-941074-7-4

Barcelona, 2013
75 páginas. Color

\section{Índice}

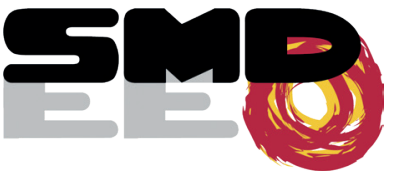

Foreward

Presentación

1. Introducción

2. Valoración muscular

3. Valoración del metabolismo anaeróbico

4. Valoración del metabolismo aeróbico

5. Valoración cardiovascular

6. Valoración respiratoria

7. Supuestos prácticos

Índice de autores

\section{Índice}

Introducción

1. Actividad mioeléctrica

2. Componentes del electrocardiograma

3. Crecimientos y sobrecargas

4. Modificaciones de la secuencia de activación

5. La isquemia y otros indicadores de la repolarización

6. Las arritmias

7. Los registros ECG de los deportistas

8. Términos y abreviaturas

9. Notas personales 